Abstracta Iranica Abstracta Iranica

Revue bibliographique pour le domaine irano-aryen

Volume 27 | 2006

Comptes rendus des publications de 2004

« Zoroastrian Scenes on a newly discovered

Sogdian Tomb in Xi'an, Northern China ». St. Ir., 33/2, (2004), pp. 273-284.

Barbara Kaim

(2) OpenEdition

Journals

Édition électronique

URL : http://journals.openedition.org/abstractairanica/5640

DOI : 10.4000/abstractairanica.5640

ISSN : 1961-960X

Éditeur :

CNRS (UMR 7528 Mondes iraniens et indiens), Éditions de l'IFRI

Édition imprimée

Date de publication : 15 mai 2006

ISSN : 0240-8910

Référence électronique

Barbara Kaim, « «Zoroastrian Scenes on a newly discovered Sogdian Tomb in Xi'an, Northern China ». St. Ir., 33/2, (2004), pp. 273-284. », Abstracta Iranica [En ligne], Volume 27 | 2006, document 44, mis en ligne le 02 janvier 2007, consulté le 25 septembre 2020. URL : http://journals.openedition.org/ abstractairanica/5640 ; DOI : https://doi.org/10.4000/abstractairanica.5640

Ce document a été généré automatiquement le 25 septembre 2020.

Tous droits réservés 


\title{
« Zoroastrian Scenes on a newly discovered Sogdian Tomb in Xi'an, Northern China ». St. Ir., 33/2, (2004), pp. 273-284.
}

\author{
Barbara Kaim
}

1 Dans la tombe découverte en 2004 dans la banlieue de Xi'an, la capitale de la province du Shaanxi, on a trouvé un sarcophage en pierre en forme de maison chinoise. Le texte bilingue raconte de la vie d'un homme nommé Shi Jun en chinois, mais Wirkak en sogdien, et de sa femme Wiyusi, pendant la dynastie des Zhou du Nord (557-581).

2 Les A. présentent l'analyse de la décoration de deux côtés du sarcophage. La figure du prêtre-oiseau, représentée deux fois sur le côté sud du sarcophage est identifiée, suivant la suggestion de 0 . Skjaervo, comme une hypostase de Srōš. Le côté est montre le franchissement du pont du Chinwad, la rencontre avec le dieu Way et la Dên, et l'arrivée à la station du Soleil. Ces thèmes sont déjà connus des ossuaires de Sogdiane mais une telle richesse de détail est exceptionnelle.

INDEX

Thèmes : 3.1. Est de l'Iran 


\section{AUTEURS}

\section{BARBARA KAIM}

Université de Varsovie 